\title{
PROJECT ACTIVITY AS A MEANS OF IMPROVING THE QUALITY OF PROFESSIONAL TRAINING OF FUTURE PHILOLOGISTS
}

Guzel A. Izmaylova

Kazan Federal University, Kazan, Russia.

Leilya R. Mukhametzyanova

Kazan Federal University, Kazan, Russia.

Natalia V. Konopleva

Kazan Federal University, Kazan, Russia.

Natalia V. Gorbunova

V.I. Vernadsky Crimean Federal University

E-mail: guzel.gulyusa@mail.ru

Recepción: 05/08/2019 Aceptación: 09/09/2019 Publicación: 23/10/2019

\section{Gitación sugerida:}

Izmaylova, G.A., Mukhametzyanova, L.R., Konopleva, N.V. y Gorbunova, N.V. (2019). Project activity as a means of improving the quality of professional training of future philologists. 3C TIC. Cuadernos de desarrollo aplicados a las TIC. Edición Especial, Octubre 2019, 164-179. doi: https://doi.org/10.17993/3ctic.2019.83-2.164-179

\section{Suggested citation:}

Izmaylova, G.A., Mukhametzyanova, L.R., Konopleva, N.V. \& Gorbunova, N.V. (2019). Project activity as a means of improving the quality of professional training of future philologists. 3C TIC. Cuadernos de desarrollo aplicados a las TIC. Special Issue, October 2019, 164-179. doi: https://doi.org/10.17993/3ctic.2019.83-2.164-179 


\section{ABSTRACT}

In the context of modernization of education and digitalization of society, one of the socially significant areas implemented in educational institutions of higher education is pedagogical design. The urgency of the problem is due to the social order of the society for the training of highly qualified specialists with critical design thinking, ready to solve professional problems of any level of complexity; the increased interest of scientists in the development of theoretical and methodological foundations of pedagogical design, on the one hand, and the lack of development of mechanisms for its practical implementation in higher education, methodological support tools for its implementation on the other. Students should select texts based on the language of their future specialty, make assignments for the consolidation of the passed terminology (Erofeeva \& Yusupova, 2018). The design background goes back to antiquity. Plato in the works "State" and "Laws" proposes and discusses the project "ideal state". Speaking as a practitioner of state building, Plato proposes to first build a state mentally, which is one of the first prerequisites for design. Scientific understanding of the process and results of design as a special activity began at the turn of $20-21^{\text {st }}$ centuries, which was characterized by the presence of reflection and design activities, the emergence of project terminology.

\section{KEYWORDS}

Project activities, Professional training, Future philologists, Pedagogical design, Methodological support. 


\section{INTRODUCTION}

The idea of the project method, put forward by the American teacher John Dewey, appeared in Russia as a "brigade method", however, not finding support, "immigrated" to the United States. The idea of project learning, which arose in the early $20^{\text {th }}$ century (Kilpatrik, 1925a, 1925b). Having become widespread and popular in schools in the US, UK, Belgium, Israel, Finland, Germany, Italy, the Netherlands, it has not been adequately reflected in Russia.

One of the advantages of project training is a rational combination of theoretical knowledge with their practical application to solve specific environmental problems in joint activities (Kudryavtsev, 1925).

In the modern system of higher education, there are three approaches to learning:

- In the first approach, the teacher determines what the student must learn, what knowledge and skills he must acquire. Training at this level is easy to control. This approach is most common. The key role is given to the "good lecturer". The result of training depends mainly on the preparedness and qualification of the trainee, while the position of the trainee as the subject of training is passive;

- The second approach is thematic: knowledge is acquired in the study of a specific topic within the framework of the educational subject. This approach is mainly focused on the interests of students and allows to establish links between previously studied areas of knowledge and new material. When working with the selected topic, the learner is more active;

- The third approach is problem-oriented, organized as a project. In this approach, students find a solution to the problem in the process of consideration and discussion of different points of view on the selected topic. The trainee is in the most active position (Šeškauskienè et al., 2011; Kheirabadi \& Mirzaei, 2019; Kashisaz \& Mobarak, 2018). 


\section{METHODS}

The willingness of teenagers to implement the idea through modern computer technologies and the ability to independently select and use art materials, techniques and their combinations according to the subject and the design task have noticeably increased (Erofeeva \& Yusupova, 2018; Eslami \& Ahmadi, 2019; Jabbari, Charbaghi, \& Dana, 2019).

In compliance with the purpose and the objects state above, the following research methods were employed at various stages of the research:

- Empirical: questioning, interviewing, testing, conversation, design; pedagogical experiment (ascertaining, forming and control stages);

- Methods of mathematical statistics: for quantitative and qualitative analysis of the results of the pedagogical experiment.

Effective communication, in its turn, is impossible without certain language skills (Kuzmina et al., 2018).

The pedagogical experiment was being conducted on the base of humanity and Education Science Academy (branch) in Yalta of V. I. Vernadsky Crimean Federal University.

\section{RESULTS AND DISCUSSION}

This study is aimed at testing the system of work on the preparation of future philologists for project activities and the use of the project method of training as a means of improving the quality of training of future philologists. Evaluation of the initial level of readiness of future philologists for project activities was carried out using criteria and diagnostic tools. For this purpose, criteria and indicators of readiness of future philologists for project activities were identified: 
- Motivational criterion with indicators: awareness of the importance of project activities in the profession of philologist; focus on the active use of project activities;

- Cognitive criterion with indicators: mastery of an integrated system of design and modeling knowledge, skills; knowledge of the features of the application of project activities in the teaching of philological disciplines;

- Operational criteria with indicators: formation of projective skills: search, communication, methodological, managerial, reflective, presentation, aimed at the creation and implementation of the project; formation of the ability to develop and present projects.

Based on the selected criteria and indicators, the levels of readiness of future philologists for project activities were characterized: threshold, productive, advanced.

To check the formation of the selected criteria and indicators, diagnostic methods of examination were selected. The selected criteria and indicators were checked by means of questioning, interviewing future philologists, testing, conversation, direct project activity.

The results of the ascertaining stage are presented in Table 1.

Table 1. Levels of readiness of future philologists for project activities at the ascertaining stage.

\begin{tabular}{|c|c|c|}
\hline Level & Experimental group & Control group \\
\hline Advanced & $5,47 \%$ & $6,32 \%$ \\
\hline Productive & $39,63 \%$ & $38,96 \%$ \\
\hline Threshold & $54,9 \%$ & $54,72 \%$ \\
\hline
\end{tabular}

Analysis of the results of the ascertaining experiment showed that most respondents had a threshold level: $54.9 \%$ in the experimental and $54.72 \%$ in the control groups. At the productive level were $39.63 \%$ of the respondents of the experimental and $38.96 \%$ of future philologists of the control groups. Advanced level detected in $5,47 \%$ of future philologists experimental and 6.32 per cent of the respondents of the control groups. 
The system of work on the preparation of future philologists for project activities was implemented in three stages, starting from the second year and continuing to the fourth: motivational and cognitive; procedural and technological; reflexive and creative. The developed system of formation of readiness of future philologists for project activities was based on the methodological principles of integrated, system-activity and contextual approaches and was a set of elements: target, substantive, procedural and evaluative. Selection of means of formation of readiness of students to project activity was carried out considering specifics and features of their professional activity.

The readiness of future philologists for project activities will be more effective in creating several pedagogical conditions:

- Activation of cognitive and mental activity of students;

- Creation of a creative atmosphere conducive to sustainable motivation for design and project activities;

- Practice-oriented nature of the educational process;

- Methodological support of the process of preparation of students of philological specialties for project activities;

- Professional and reflexive self-identification of the future philologist considering the specifics of the project activities.

The system of work provided for the formation of projective skills of future philologists: search; communicative; methodical; managerial; reflective; presentation.

At the first, motivational and cognitive stage (the $2^{\text {nd }}$ year of learning) the following tasks were solved: to determine the level of cognitive activity of students; to acquaint with the essence of project activities; the importance of preparation for project activities. Effective at this stage were such forms of work as monitoring the work of teachers of Philology and its analysis in the period of pedagogical practice, conversations, round table, lectures, trainings. 
The objectives of the procedural and technological stage (the $3^{\text {rd }}$ year of learning) were: to form projective skills; to improve special knowledge in the field of project activities and the ability to create their own projects of linguistic orientation. In order to solve the selected tasks, this stage was aimed at the gradual formation of such projective skills: the ability to consciously perceive information, the ability to listen to the interlocutor and analyze information, the ability to conduct a dialogue (checking the speech and theoretical readiness of students to organize project activities in the primary school), distribute work among team members according to their skills (Executive aspect), organize work in a group, predict the course of events, monitor and evaluate the work of the group (control and corrective aspect).

The reflexive-creative stage (the $4^{\text {th }}$ year of learning) of training of future teachers of philological specialties was aimed at the development, presentation and public protection of research, information, professional, practice-oriented projects. At the third stage of work the following tasks were solved: to improve projective skills, to develop creative potential of the person in the process of preparation of research, information, professional, practice-oriented projects.

The control stage of the experiment was carried out in order to check the effectiveness of the work on the preparation of future philologists for project activities. To this end, future philologists were asked to perform diagnostic techniques like the tasks of ascertaining experiment: questioning, interviewing, testing, conversation, direct project activities.

A comparative analysis of the study results for the experimental and control groups is presented in Table 2 .

Table 2. Comparative levels of readiness of future philologists for project activities.

\begin{tabular}{|c|c|c|c|c|}
\hline Groups & \multicolumn{2}{|c|}{ Experimental group } & \multicolumn{2}{|c|}{ Control group } \\
\hline Levels & $\begin{array}{c}\text { Ascertaining } \\
\text { experiment }\end{array}$ & $\begin{array}{c}\text { Control } \\
\text { experiment }\end{array}$ & $\begin{array}{c}\text { Ascertaining } \\
\text { experiment }\end{array}$ & $\begin{array}{c}\text { Control } \\
\text { experiment }\end{array}$ \\
\hline Advanced & $5,47 \%$ & $20,94 \%$ & $6,32 \%$ & $8,96 \%$ \\
\hline
\end{tabular}




\begin{tabular}{|c|c|c|c|c|}
\hline Groups & \multicolumn{2}{|c|}{ Experimental group } & \multicolumn{2}{|c|}{ Control group } \\
\hline Levels & $\begin{array}{c}\text { Ascertaining } \\
\text { experiment }\end{array}$ & $\begin{array}{c}\text { Control } \\
\text { experiment }\end{array}$ & $\begin{array}{c}\text { Ascertaining } \\
\text { experiment }\end{array}$ & $\begin{array}{c}\text { Control } \\
\text { experiment }\end{array}$ \\
\hline Productive & $39,63 \%$ & $64,3 \%$ & $38,96 \%$ & $42,69 \%$ \\
\hline Threshold & $54,9 \%$ & $14,76 \%$ & $54,72 \%$ & $48,35 \%$ \\
\hline
\end{tabular}

As follows from the comparative analysis of the results of experimental work, the level of readiness of future philologists for project activities was increased. There have been significant positive changes in the experimental group. The number of respondents with advanced (from $5.47 \%$ when ascertaining to $20.94 \%$ during the control survey) and productive (from 39.63\% during the ascertaining survey to $64.3 \%$ during the control experiment) levels significantly increased and the number of future philologists with a threshold level of readiness for project activities decreased (from $54.9 \%$ when ascertaining to $14.76 \%$ during the control survey).

The control group also experienced positive changes, although less significant. Thus, the number of respondents with advanced (from 6.32\% during the ascertaining experiment to $8.96 \%$ during the control survey) and productive (from $38.96 \%$ in the ascertaining experiment to $42.69 \%$ during the control experiment) levels increased and the number of students with a threshold level decreased slightly (from $54.72 \%$ when ascertaining to $48.35 \%$ in the control survey).

The pedagogical approach of Roskilde University is based on the idea that the student will better master the professional training if he starts with the search and formulation of the problem about interest to him. The formulated problem should be realized by the group members as real and its solution should be found within one of the educational cycles chosen by the student: humanitarian, humanitarian-technological, natural science or social (Berthelsen et al., 1985).

Work on the method of problem-oriented project is based on five grounds:

1. Problem statement: what is accepted as the main question of the projectwhat do you want to explore? 
2. Research objective: why do you want to research this?

3. Empirical base of research: what factual material will be used to solve the problem?

4. Theoretical basis of the research: within the framework of which theory will you investigate the selected problem and using what methods?

5. Methods of research: how will you carry out the planned search? (Papandreou, 1994).

One of the functions of the teacher in the role of project Manager is facilitation of the educational process. It is important that the teacher can ask problematic and leading questions, create a friendly atmosphere in the group, a positive attitude to solving problems, and not a direct guide, devoid of direct hints or prohibitions (Olsen \& Pedersen, 2003; Yepaneshnikov et al., 2017).

Creative activity within the educational project is considered as a combination of conscious psychological phenomena (synthesis, analysis, comparison, analogy) and unconscious. The activities under consideration include the following stages: data search, data study and development of new ones. The author interprets the educational project as a special didactic regime, as a cognitive and creative cooperation. The project includes three components: motive, innovative technologies and creative potential and the following stages: formation of educational space improvement; model to achieve the goals related to the creativity of students' activity; appropriate pedagogical conditions (Ignatieva et al., 2018; Mailybaev et al, 2018; Nakhaee \& Nasrabadi, 2019).

In the article by Reshetnikova (2013), the methods of training the creativity of future teachers in the process of studying philological disciplines are considered. The analysis of the literature allowed to identify such methods that are important for the process of formation of creative potential of students, based on role and problem-situational problems that affect different spheres of personality: cognitive, emotional, motivated and psychological. 
Modern philologist should not only transfer the experience of previous generations to new generations, but also to form an appropriate level of language learning, the desire for constant updating of knowledge, skills of self-education in the field of foreign language, be ready to interact in a foreign language environment, using active teaching methods. This is provided by mastering the knowledge and skills of using interactive technologies in professional activities, which are a set of interrelated actions that create pedagogical conditions, the implementation of which ensures the formation of the studied phenomenon (Lypchanko-Kovachyk, 2017).

Interest in project work and its integration into second and foreign language learning is growing worldwide. The project work leads to the purposeful use of language, as it requires the personal participation of students: from the very beginning of the project, students, in consultation with their teacher, must decide "what they will do and how they will do it". This includes not only the content of the project, but also the language requirements. Work on the project includes a variety of skills that focus on the topic of interest, rather than on specific language tasks (Sheppard \& Stoller, 1995).

\section{SUMMARY}

The specificity of the preparation of future philologists for project activities is due to the inclusion in the activities of adequate readiness, which is formed (the ability to "include" in the project, to carry out all stages of project activities, the ability to overcome psychological barriers during inclusion in the project activities).

However, at the present stage, schoolchildren are often not able to empathize, they are inclined to pragmatic reading, to receive information, and only during the analysis of a fictional work can they understand the depth of the text's intention and experience certain emotions (Kayumova et al., 2018). 
The state of the problem of preparing future philologists for project activities in foreign and domestic pedagogy is studied. In this regard, the project activities of future philologists are considered as an integrated activity, synthesizing cognitive, educational, communicative, creative activities, having a common goal, consistent methods, methods of activity aimed at achieving a common result.

A comparative analysis of the results of the experimental work showed an increase in the number of respondents with the level of readiness of future philologists of the experimental group for project activities, where significant positive changes in the redistribution of levels were revealed.

\section{CONCLUSION}

The study does not exhaust all aspects of the problem. The promising areas of research include: the improvement of didactic and methodological support, the use of information and communication technologies to prepare future philologists for project activities; the development of professional mobility of future philologists.

\section{ACKNOWLEDGEMENTS}

The work is performed according to the Russian Government Program of Competitive Growth of Kazan Federal University.

\section{REFERENCES}

Berthelsen, J., Illeris, K., \& Poulsen, S. G. (1985). Grundbog i projektarbejde: teori og praktisk vejledning. - Kbh.: Unge Pædagoger.

Erofeeva, A. A., \& Yusupova, Z. F. (2018). Actual problems of teaching russian language as the language of the specialty of foreign students. Revista Publicando, 5(16(1)), 324-331. Retrieved from https://revistapublicando.org/ revista/index.php/crv/article/viewFile/1503/pdf_1104 
Eslami, R., \& Ahmadi, S. (2019). Investigating the Role of Educational Media on Secondary School Students' Learning Process Improvement in Jahrom City. Fournal of Humanities Insights, 3(01), 13-16. doi: https: / / doi.org/10.22034/ jhi.2019.80890

Ignatieva, G., Vilkova, A., Timofeeva, E., Donskova, N., \& Smorodinskova, I. (2018). Educational Project as a way of improving students' creative activity. Revista Espacios, 39(25). Retrieved from http://www. revistaespacios.com/a18v39n25/a18v39n25p23.pdf

Jabbari, E., Charbaghi, Z., \& Dana A. (2019). Investigating the Effects of Educational and Motivational Education at Different Levels on the Performance and Application of dart throwing. Fournal of Humanities Insights, 3(02), 37-44. doi: https://doi.org/10.22034/jhi.2019.80896

Kashisaz, S., \& Mobaraki, E. (2018). The Effects of Private Education Institutes in Providing Modern Financial Knowledge in Developing Countries. Journal of Humanities Insights, 02(04), 172-178.

Kayumova, G. F., Makarova, V. F., \& Galiullin, R. R. (2018). Moral education of high school students in national (TurkiC) schools through literature. International Fournal of Mechanical Engineering and Technology, 9(10), 14671475. Retrieved from http:/ /www.iaeme.com/MasterAdmin/UploadFolder/ IJMET_09_10_150/IJMET_09_10_150.pdf

Kheirabadi, M. A., \& Mirzaei, Z. (2019). Descriptive valuation pattern in education and training system: a mixed study. Fournal of Humanities Insights, 3(01), 7-12. doi: https://doi.org/10.22034/jhi.2019.80889

Kilpatrick, W.H. (1925a). Método del proyecto. El uso de la fijación de objetivos en el proceso pedagógico. [In Russian]

Kilpatrick, W.H. (1925b). Los fundamentos del método. [In Russian]

Kudryavtsev, V.T. (1925). Educación problemática: fuentes, esencia, perspectivas. Conocimiento. [In Russian] 
Kuzmina, E. K., Nazarova, G. I., \& Nizamieva, L. R. (2018). Innovative technologies of teaching business French. International fournal of Engineering and Technology (UAE), 7(4), 85-87. Retrieved from https://www.sciencepubco. com/index.php/ijet/article/view/20390/9555

Lypchanko-Kovachyk, O. (2017). Pedagogical conditions for training students of english philology for use of interactive technologies in their future professional activity. Social work and education, 4(2), 102-115. Retrieved from http://journals.uran.ua/swe/article/view/118977

Mailybaev, G. S., Zhexembayeva, Z. R., Nurgaliyeva, S. A., Zholumbayeva, R. M., \& Utegulov, D. E. (2018). The efficiency of the education system in Kazakhstan: Programme for International Student Assessment (PISA). Opción, 34(85-2), 600-626. Retrieved from http://www. redalyc.org/jatsRepo/310/31057290025/html/index.html

Nakhaee, J., \& Nasrabadi, M. A. (2019). Strategies for Research-Centered Education of Architectural Designing by Examining the Research-Centered Activities of the Top Universities. Fournal of Humanities Insights, 3(02), 50-6. doi: https://doi.org/10.22034/jhi.2019.80898

Olsen, P. B., \& Pedersen, K. (2003). Frederiksberg: Roskilde universitetsforlag.

Papandreou, A. P. (1994). An application of the projects approach to EFL. In English Teaching Forum, 32(3), 41-42.

Reshetnikova, A. B. (2013). Creativity Enhancing Methods in the Educational Process. American Fournal of Educational Research, 1(11), 543-547. Retrieved from https://pdfs.semanticscholar. org/7898/9fa468d871232c54a3065bb39b6f5d17c9ca.pdf

Šeškauskienè, I., Gibulskienė, J., Kalèdaitè, V., \& Roikienè, D. (2011). Guidelines of competence development in the study field of english philology. Lithuanian University of Education. - October 18, 61 p. 
Sheppard, K., \& Stoller, F. L. (1995). Guidelines for the integration of student projects into ESP classrooms. In English Teaching Forum, 33(2), 10-15.

Yepaneshnikov, V. V., Kurdyumov, V. I., Zotova, L. E., Kraeva, M. U., Besedkina, N. I., \& Filipenkova, O. G. (2017). Individual Educational Paths of Students' Cognitive Activity Development. International Electronic Fournal of Mathematics Education, 12(1), 79-87. Retrieved from https://www. iejme.com/article/individual-educational-paths-of-students-cognitiveactivity-development 
Edición Especial Special Issue Octubre 2019 DOI: https://doi.org/10.17993/3ctic.2019.83-2.164-179 